\title{
PERAN BADAN USAHA MILIK DESA DALAM PENGELOLAAN OBJEK WISATA DI DESA DENAI LAMA KECAMATAN PANTAI LABU KABUPATEN DELI SERDANG
}

\author{
Nurmaulida Saragi, Abdullah \\ Program Studi Pengembangan Masyarakat Islam, Fakultas Dakwah dan Komunikasi, \\ Universitas Islam Negeri Sumatera Utara
}

\begin{abstract}
Abstrak: Tujuan Penelitian ini untuk mengetahui peran yang di lakukan Badan Usaha Milik Desa dalam pengelolaan objek wisata di Desa Denai Lama Kecamatan Pantai Labu Kabupaten Deli Serdang, dan untuk mengetahui program Badan Usaha Milik Desa dalam meningkatkan ekonomi masyarakat serta untuk mengetahui faktor pendukung dan penghambatnya. Metode yang digunakan dalam penelitian ini adalah metode kualitatif, dengan menggunakan observasi, wawancara, dan dokumentasi. Adapun yang menjadi informan dalam penelitian ini adalah Sekretaris Desa, Badan Usaha Milik Desa yang meliputi Ketua Bumdes, Sekretaris Bumdes dan masyarakat Desa Denai Lama. Teknik analisis data dalam penelitian ini adalah reduksi data, penyajian data, dan menarik kesimpulan/verifikasi. Hasil yang telah diperoleh dalam penelitian ini bahwa Badan Usaha Milik Desa sangat berperan dalam meningkatkan ekonomi masyarakat Desa Denai Lama melalui pengelolaan objek wisata, karena banyak dari masyarakat Desa Denai Lama yang sebelumnya memiki ekonomi rendah, setelah adanya objek wisata dapat di lihat ekonomi masyarakat meningkat melalui program-program yang di berikan Bumdes.
\end{abstract}

Kata Kunci: Peran, BUMDes, Objek Wisata,

\section{PENDAHULUAN}

Desa merupakan unit terkecil dari negara yang terdekat adapun masyarakat dan secara riil langsung menyentuh kebutuhan masyarakat untuk di sejahterakan. Sebagai Wakil negara, desa wajib melakukan pembangunan baik pembangunan fisik maupun pembangunan sumber daya manusia, sebagai upaya peningkatan kualitas hidup dan kehidupan untuk sebesar-besarnya kesejahteraan masyarakat desa. ${ }^{1}$ Berdasarkan asumsi itulah maka sudah seharusnya eksistensi desa mendapatkan perhatian yang serius dari pemerintah pusat dengan lahirnya kebijakan-kebijakan terkait dengan pemberdayaan ekonomi yang dilakukan dengan cara menghimpun dan melembagakan kegiatan ekonomi masyarakat.

\footnotetext{
${ }^{1}$ Maria Rosa Ratna Sri Anggraeni, Peranan Badan Usaha Milik Desa Pada Kesejahteraan Masyarakat Pedesaan Studi Pada Bumdes Di Gunung Kidul, Yogyakarta ( Jurnal MODUS Vol.28 (2) : 155-157, 2016 )

Nurmaulida Saragi, Abdullah |

Peran Badan Usaha Milik Desa dalam Pengelolaan Objek Wisata di Desa Denai Lama Kecamatan Pantai Labu Kabupaten Deli Serdang
} 
Tahun 2015 merupakan tahun pertama dilaksanakannya UU No. 6 Tahun 2014 Tentang Desa, yang merupakan bagian dari ikhtiar mencapai keberdayaan negara dan bangsa Indonesia dari kemandirian desa-desanya. Adapun untuk mewujudkan Desa yang mandiri diperlukan adanya strategi pembangunan. Diberlakukannya Undang-undang Nomor 6 Tahun 2014 Tentang Desa maka menjadi peluang yang sangat besar bagi setiap desa yang ada di Indonesia untuk bisa mengembangkan setiap potensi yang dimilikinya secara mandiri sesuai kebutuhan masing-masing dalam rangka mewujudkan kesejahteraan masyarakat. Untuk menggerakkan roda perekonomian di pedesaan maka didirikannya lembaga ekonomi desa, salah satunya adalah BUMDes (Badan Usaha Milik Desa).

Badan Usaha Milik Desa (BUMDes) merupakan salah satu lembaga perekonomian desa yang sepenuhnya dikelola oleh masyarakat. Sebagai salah satu program andalan dalam meningkatkan kemandirian dan kreativitas masyarakatnya, maka BUMDes perlu didirikan.

Salah satu desa yang telah mendirikan program BUMDes adalah Desa Denai Lama yang berada di Kecamatan Pantai Labu Kabupaten Deli Serdang. BUMDes Sastro 316 didirikan pada 16 februari 2016. Pendirian BUMDes ini berdasarkan hasil musyawarah Desa No. 14/05/ST/VIII/Tahun 2016. Desa Denai Lama mempunyai program di bidang sektor pertanian, sektor objek wisata dan seni budaya akan tetapi saya lebih fokus untuk penelitian dibagian objek wisata nya karena melalui ini masyarakat memiliki kesempatan mendapatkan pekerjaan baru sehingga masyarakat mendapatkan penghasilan tambahan untuk meningkatkan perekonomian mereka.

Indonesia sebagai negara yang kaya potensi wisata mempunyai perhatian khusus terhadap perkembangan dan pengembangan industri pariwisata di harapkan dapat memacu pertumbuhan perekonomian Indonesia selain bermanfaat untuk meningkatkan lapangan kerja, perkembangan pariwisata juga bertujuan untuk memperkenalkan budaya dan keindahan alam indonesia. Banyak faktor yang mendorong seseorang untuk melakukan perjalanan wisata, diantaranya karena ingin melihat tempat - tempat baru yang belum pernah di kunjungi dan ingin belajar 
kebudayaan dari daerah yang dikunjungi, menghindari udara atau musim yang tidak mengenakkan, keinginan untuk melakukan sesuatu yang tidak bisa dilakukan di rumah, untuk sekedar rekreasi atau rilaks, menikmati keindahan alam dan lainnya. Dalam hal ini faktor alam juga sangat berpengaruh seperti iklim, pemandangan alam, flora dan fauna, sumber air mineral, dan lain - lain. Selain itu, ada pula faktor yang merupakan hasil ciptaan manusia seperti kebudayaan, tradisi dan adat istiadat dari penduduk setempat, benda-benda bersejarah, tarian dan upacara tradisional masyarakat setempat. ${ }^{2}$

Tidak hanya di Medan yang mempunyai rekreasi wisata yang sangat indah. Tetapi Desa denai Lama Kabupaten Deli Serdang juga memiliki wisata alam yang sangat indah yang dikelilingi hamparan sawah hijau yang dapat menyegarkan mata para pengunjung. Berawal dari keinginan untuk mengembangkan dan memperkenalkan Paloh Naga, menjadi alasan hadirnya Agrowisata Paloh Naga saat ini. Indahnya pemandangan area persawahan yang luas dan hijau menjadi salah satu spot wisata yang ditawarkan tempat wisata yang berada di Desa Denai Lama, Pantai Labu, Deli serdang, Sumatera Utara. Motivasi Bumdes untuk membuat dan mengelola wisata alam ini dikarenakan Desa Denai Lama pernah mengikuti Festival Garapan Tradisional Deliserdang, lalu mendapatkan juara pertama saat membawa nama Paloh Naga tersebut oleh karena itu ingin mengembangkan dan mengangkat sejarah Dari Paloh Naga sendiri untuk dikenal orang lebih banyak lagi. ${ }^{3}$

Desa wisata Denai Lama merupakan Desa Wisata pertama yang ada di Kabupaten Deli Serdang, atas inisiatif Kepala Dinas Kepemudaan, Olahraga, Kebudayaan dan Pariwisata Kabupaten Deli Serdang, H. Faisal Arif Nasution, M.Si, desa wisata ini terbentuk dengan melibatkan pemerintah desa setempat dan stakeholder untuk membangun citra pariwisata baru di Kabupaten Deli Serdang. Desa wisata ini dikelola oleh Badan Usaha Milik Desa (BUMDES), pembangunan sarana dan prasarananya bersumber dari Dana Desa dan partisipasi BUMD yang ada di

\footnotetext{
${ }^{2}$ SM Situmorang, Objek wisata Kebun binatang Simalingkar B dalam kajian Sejarah Pariwisata tahun 2005-2011, ( Medan : Universitas Negeri Medan, 2012 ) h.1

${ }^{3}$ https://www.pariwisatasumut.net di akses tanggal 5 Februari 2019 Pukul 10.30 WIB. 
Kabupaten Deli Serdang. Agrowisata Paloh Naga di Deli Serdang merupakan objek wisata yang mengandalkan keindahan alam sebagai daya tariknya. Berada di lokasi ini Anda akan mendapatkan suguhan dari hijaunya petak-petak sawah yang membentang seluas mata memandang. Area persawahan yang luas, jadi atraksi utama yang langsung mampu menarik minat banyak pengunjung. Berfoto dengan latar belakang sawah hijau yang menyegarkan, berpadu dengan birunya langit, sungguh sangat instagenic. Pengelola menyediakan jembatan bambu sengaja dibangun untuk menjadi spot tracking sekaligus selfie. ${ }^{4}$

Berdasarkan latar belakang masalah di atas, maka peneliti tertarik untuk melakukan peneitian tentang Peran Badan Usaha Milik Desa dalam Pengelolaan Objek wisata di Desa Denai Lama Kecamatan Pantai Labu Kabupaten Deli Serdang.

\section{METODELOGI PENELITIAN}

Penelitian ini dilakukan di Desa Denai Lama Kecamatan Pantai Labu Kabupaten Deli Serdang. Adapun peneliti memilih di Desa Denai Lama Kecamatan Pantai Labu Kabupaten Deli Serdang karena lokasi tersebut memiliki objek wisata yang sangat indah dengan di kelilingi pemandangan hijau dan pengunjung dapat menikmatinya dan juga mempunyai rumah produksi yang sangat menarik meningkatkan kesejahteraan masyarakat serta seni budaya tradisional tari serampang 12 yang masih melekat dan tidak pernah tinggal. Desa ini seluas 295,5 hektare ini memiliki empat dusun Jarak desa dari Kecamatan Pantai Labu sekitar 8,2 Km dan jarak desa dari Kabupaten Deli Serdang sekitar 52,1 Km.

Penelitian ini menggunakan jenis penelitian kualitatif dengan menggunakan pendekatan deskripsi kualitatif. Tujuan penelitian kualitatif adalah untuk mendapatkan uraian mendalam tentang ucapan, tingkah laku yang dapat di amati dari suatu individu, kelompok masyarakat atau organisasi tertentu yang di kaji dari sudut pandang yang utuh dan menyeluruh. Subjek yang di teliti dalam hal ini adalah Peran

\footnotetext{
${ }^{4}$ https://travellingyuk.com.agrowisata.palohnaga diakses tanggal 05 Februari 2019 Pukul 10.30 WIB

Nurmaulida Saragi, Abdullah |

Peran Badan Usaha Milik Desa dalam Pengelolaan Objek Wisata di Desa Denai Lama Kecamatan Pantai Labu Kabupaten Deli Serdang
} 
Bumdes dalam Pengelolaan Objek Wisata di Desa Denai lama Kecamatan Pantai labu Kabupaten Deli serdang.

Informan penelitian berjumlah 6 orang dari masyarakat Desa Denai Lama Kecamatan Pantai Labu Kabupaten Deli Serdang mereka yang mampu memberikan informasi dan mereka masyarakat yang bertempat tinggal di desa tersebut. Terdapat pada tabel dibawah ini :

\section{Tabel 1}

\section{Informan Penelitian}

\begin{tabular}{|c|c|c|c|}
\hline No & Nama & Pekerjaan & Umur \\
\hline 1 & Pak Irwanto & Ketua Bumdes & 42 tahun \\
\hline 2 & Bang Halim Syahbana & Sekretaris Bumdes & 30 tahun \\
\hline 3 & Pak Mesdianto & Sekretaris Desa & 50 tahun \\
\hline 4 & Pak Saiful & Petani & 47 tahun \\
\hline 5 & Ibu Sumiati & Petani, Ibu Rumah Tangga & 45 tahun \\
\hline 6 & Ibu Suyiati & Jualan, Ibu rumah tangga & 37 tahun \\
\hline
\end{tabular}

\section{Metode Pengumpulan Data}

Untuk mendapatkan data yang diperlukan, maka teknik pengumpulan data yang dilakukan dengan cara :

\section{Obervasi ( Pengamatan )}

Merupakan metode pengumpulan data yang dilakukan peneliti untuk mengamati pengelolaan objek wisata dan ekonomi masyarakat dengan adanya dibuat objek wisata dan mencatat suatu peristiwa dengan penyaksian langsungnya, dan biasanya peneliti dapat sebagai partisipan atau observer dalam menyaksikan atau mengamati suatu objek peristiwa yang sedang di teliti nya 


\section{Wawancara}

Wawancara merupakan metode pengumpulan data yang menggunakan tanya jawab untuk mendapatkan tanggapan dari responden atau key informan yang diteliti berlandaskan pada tujuan penelitian.

\section{Dokumentasi}

Dilakukan oleh peneliti untuk melakukan kontak dengan pelaku atau sebagai partisipan yang terlibat pada suatu peristiwa sejarah masa lalu dan terdapat dua jenis dokumentasi yang dipergunakan dalam metode ini, yaitu :

a. Data archival ( arsif)

b. Dokumen $(\text { sejarah })^{5}$

\section{Sumber data}

Adapun aktifitas yang dilakukan adalah membuat basis data kasus dengan menggunakan berbagai metode pengumpulan data, baik data kualitatif maupun kuantitatif. Dalam penelitian ini untuk sumber dan jenis data yang diperlukan, yaitu :

1. Data Primer

Sumber dan jenis kata primer penelitian ini adalah kata-kata dan tindakan subjek serta gambaran ekspresi, sikap dan pemahaman dari subjek yang di teliti sebagai dasar utama melakukan interprestasi data. Sedangkan untuk pengambilan data dilakukan dengan bantuan catatan lapangan, bantuan foto atau bila memungkinkan dengan bantuan rekaman suara tape recorder dan observasi mendalam oleh peneliti.

\section{Data sekunder}

Berbagai sumber tertulis yang memungkinkan dapat di manfaatkan dalam penelitian ini akan digunakan semaksimal mungkin demi mendorong keberhasilan penelitian ini. Diantaranya buku-buku, literatur, internet, majalah, atau jurnal ilmiah, arsip, dokumentasi pribadi, dan dokumen resmi lembaga-lembaga yang terkait

\footnotetext{
${ }^{5}$ Rosady Ruslan, Metode Penelitian Public Realitions dan Komunikasi, ( Jakarta : Rajawali
} Pers, 2017 ), h. 221-222 
dengan penelitian ini. Pada fungsi yang optimal dapat memberikan pemahaman teoritik dan metodologi yang melandasi dalam melakukan penelitian yang benar ${ }^{6}$

\section{Teknik Analisa Data dan Keabsahan Data}

Penelitian ini adalah penelitian kualitatif, maka datanya dipaparkan dengan cara deskriptif. Setelah semua yang dibutuhkan terkumpul, maka selanjutnya penulis melakukan analisa terhadap data-data tersebut. Untuk proses analisa data maka penganalisa dilakukan dengan analisa domain (domain analysis) maksudnya adalah penelitiannya di target untuk memperoleh gambaran seutuhnya dari objek yang diteliti tanpa harus merinci secara detail unsur-unsur yang ada dalam keutuhan objek yang diteliti.

Menurut Miles dan Huberman seperti yang dikutip secara bersamaan, yaitu di kutip oleh Ulber. Kegiatan analisa terdiri tiga alur kegiatan yang dilakukan secara bersamaan, yaitu reduksi data, penyajian data, dan penarikan kesimpulan/verifikasi.

1. Reduksi data di artikan sebagai proses pemilihan pemusatan perhatian pada penyederhanaan, pengabstrakan, dan transformasi data kasar yang muncul dari catatan-catatan yang tertulis di lapangan.

2. Penyajian data yaitu sebagai sekumpulan informasi tersusun yang memberkemungkinan adanya penarikan kesimpulan dan pengambilan tindakan.

3. Menarik kesimpulan verifikasi ${ }^{7}$

Adapun teknik kebasahan data dalam penelitian ini menggunakan triangulasi Burhan Bungin menjelaskan bahwa hal ini dapat tercapai dengan cara yaitu :

1. Membandingkan data hasil pengamatan dengan hasil wawancara.

2. Membandingkan apa yang dikatakan orang di depan umum dengan apa yang dikatakan secara pribadi

3. Membandingkan dengan apa yang dikatakan orang-orang tentang situasi penelitian dengan apa yang dikatakan sepanjang waktu

\footnotetext{
${ }^{6}$ Lisa Harrison, Metodologi Penelitian politik, ( Jakarta : Kencana, 2007 ), h. 35

${ }^{7}$ Ulber silalahi, Metode Penelitian Sosial, ( Bandung : PT Refika Aditama 2009 ), h.339 Nurmaulida Saragi, Abdullah | Peran Badan Usaha Milik Desa dalam Pengelolaan Objek Wisata di Desa Denai Lama Kecamatan Pantai Labu Kabupaten Deli Serdang
} 
4. Membandingkan keadaan dan perspektif seseorang dengan berbagai pendapat dan pandangan orang seperti rakyat biasa, orang yang berpendidikan menengah atau tinggi dan pemerintahan.

5. Membandingkan hasil wawancara dengan isi suatu dokumen yang berkaitan ${ }^{8}$

\section{HASIL PENELITIAN}

\section{Program Badan Usaha Milik Desa Sastro 3-16 dalam mengelola objek wisata}

Indonesia yang kita ketahui yaitu kaya dengan Sumber Daya Alam. Kekayaan yang kita punya dapat dimanfaatkan sebaik-baiknya salah satu bukti kita menjaga lingkungan di sekitar yaitu dengan melestarikan dan mengelolanya dengan mendatangkan para wisatawan dari manca negara, melihat keindahan alam akan menghasilkan peningkatan ekonomi masyaraka,t salah satu program Badan Usaha Milik Desa di Desa Denai Lama membuat suatu objek wisata yang berasal dari kekayaan yang mereka punya yaitu hamparan sawah masyarakat sekitar 35 hektar. Bumdes sastro 3-16 beserta anggota lainnya mengelolanya dengan membuat jembatan dari bambu seluas 10 hektar dan spot selfi lainnya membuat banyak para pengunjung datang menikmati keindahan alam yang ada di Desa Denai Lama dihiasi dengan hamparan petak-petak sawah yang sangat luas memandang.

Pertama, Program Badan Usaha Milik Desa yaitu menyediakan fasilitas di objek wisata yaitu jembatan bambu, spot foto, rumah produksi dan budaya sanggar tari. Berkunjung di objek wisata para wisatawan hanya membayar tiket karcis Rp.5000,- sudah menikmati kesejukan khas desa yaitu keindahan sawah yang membentang di lengkapi dengan spot foto. Para pengunjung yang datang tidak hanya datang melihat keindahan alam tetapi para pengunjung bisa belajar bagaimana cara pembuatan padi yang dimulai dengan belajar menanam dan sampai panen bahkan terjun langsung ke sawah bersama petani. Anak-anak generasi bangsa juga boleh ikut mengetahui proses padi yang ditanam sehingga menghasilkan nasi yang mereka makan. Anak-anak modern sekarang harus mengetahui ada jerih payah dan

\footnotetext{
${ }^{8}$ Burhan Bungin, Penelitian Kualitatif, ( Jakarta : Prenada Media Group, 2007 ), h.265 
perjuangan seorang petani yang selama ini ikut berjasa dalam kehidupan kita bahwa kita di kehidupan ini saling membutuhkan satu sama lain dan tidak bisa hidup berdiri sendiri. Bermain menikmati sejuk alam sambil belajar disinilah salah satu letak peran Badan Usaha Milik Desa Denai Lama mengajarkan anak-anak dan mengenalkan mereka bahwa alam yang di titip Sang Pencipta itu tidak untuk di rusak tetapi di pelihara, di jaga dan di lestarikan akan berdampak baik terhadap lingkungan sekitar.

Kedua, Program Badan Usaha Milik Desa untuk meningkatkan ekonomi masyarakat serta mensejahterakan masyarakat yaitu menyediakan gedung Pusat Kegiatan Belajar Masyarakat-Rumah Produksi (PKBM) yang berdiri pada tahun 2018 yang telah diresmikan oleh Bapak H.Ashari Tambunan selaku Bupati Deli Serdang dan di bantu oleh Angkasa Pura II. Rumah Produksi yang disediakan oleh pihak Bumdes untuk ibu-ibu UMKM sangat membantu mereka terutama dalam tingkat ekonomi. Bakat selama ini terpendam bisa disalurkan dengan adanya rumah produksi tersebut seperti membuat makanan seperti dodol, kue, pelatihan menjahit dan kerajinan tangan. Ibu-ibu UMKM juga bersedia jika para pengunjung yang datang ingin belajar bagaimana cara pembuatan dodol, kue, keterampilan menjahit dan juga kerajinan tangan maka ibu-ibu UMKM siap melayani dan mengajari para pengunjung yang mau belajar. Pemasaran yang di lakukan ibu-ibu UMKM ini pada saat ada salah satu pengunjung wisatawan memesan makanan maupun kerajinan tangan dan pada saat ada bazar baik di tingkat kecamatan maupun kabupaten. ${ }^{9}$

Ketiga, Program Badan Usaha Milik Desa yaitu seni budaya. Seni tari di Desa Denai Lama di bina oleh Disporabudpar yang berdiri sejak tahun 2003 yang di pimpin oleh Bapak Irwanto, SH. Diberikan nama sanggar lingkaran yaitu saat anakanak Desa Denai Lama belajar dan diskusi mereka membuat berbentuk lingkaran supaya mudah mengenal satu sama lain dan menjalin silaturahmi. Sanggar Lingkaran mengajarkan tentang budaya untuk membangun karakter dari laskar-laskarnya yang bersumber langsung dari keluarga dan masyarakat sekitar. Sanggar Lingkaran

\footnotetext{
${ }^{9}$ Bapak Irwanto,Ketua Bumdes, Program Badan Usaha Milik Desa, Wawancara Pribadi, Sanggar Lingkaran, 13 Mei 2019 Pukul 11:30 WIB. 
menggunakan beberapa media seni sebagai pendekatan dalam penyampaian materimateri dengan muatan pengembangan karakter seperti; seni menggambar, seni musik, tari dan seni teater, kemudian pendidikan-pendidikan kepemimpinan melalui kegiatan outbond, di lakukan setiap enam bulan sekali. Sanggar Lingkaran mengadakan berbagai kegiatan untuk membangun nilai-niai karakter dari anak-anak di Desa Dusun Denai Lama karena pemilik sanggar melihat dengan kemajuan yang ada saat ini membuat anak-anak di Desa mereka menjadi lupa akan kebudayaan mereka dan mereka malu-malu untuk mengenalkan kebudayaan mereka terutama dibidang tarian, sehingga memunculkan minat dari pemilik sanggar untuk dapat memotivasi serta mewadahi anak-anak disana agar dapat lebih mengenal, menghargai dan meneruskan kebudayaan yang ada agar tidak tersisih dengan adanya kemajuan yang terus berkembang.

Melihat banyaknya karakter yang harus diajarkan kepada anak-anak di sanggar, pihak sanggar mengunakan tenaga-tenaga relawan yang membantu sesuai dengan bagiannya sendiri. Relawan-relawan tersebut merupakan alumni dari sanggar tersebut. Relawan di sanggar sebanyak 20 orang, tetapi hanya 7 orang relawan saja yang masih aktif mengajar di sanggar karena beberapa dari mereka memiliki kesibukan di luar sanggar seperti bekerja, menempuh pendidikan di luar kota bahkan sudah menikah. Anak-anak yang di ajar di sanggar adalah anak-anak yang berusia 8 tahun sampai dengan 18 tahun. Melihat pendidikan karakter merupakan salah satu aspek penting yang menjadi faktor kesuksesan manusia di masa depan. Sanggar menciptakan suasana yang asik, menarik dan bersifat aktif yang akan memudahakan anak-anak sanggar mengingat apa yang dipelajarinya selama di sanggar. Pemilik sanggar memiliki kayakinan bahwa manusia-manusia yang berkarakter tidak perlu diragukan bahwa dia akan memiliki kesuksesan, karena dimana orang yang memiliki kelakuan baik, pasti dia akan dikelilingi dengan kegiatan dan orang-orang yang baik pula. Tidak dapat dipungkiri dengan penanaman nilai-nilai budaya yang baik pasti akan mendukung keberhasilan dalam program pendidikan karakter. Disinilah peran dari sanggar itu sendiri, tentunya sanggar yang satu dengan sanggar yang lain 
memiliki karakter yang berbeda-beda sesuai keunggulannya dan nilai-nilai karakter yang ditekankan di sebuah sanggar tari.

\section{Peningkatan Ekonomi Masyarakat}

Berbicara tentang ekonomi, ekonomi adalah suatu hal yang terpenting di dalam kehidupan manusia yang mana ekonomi di kelola oleh sumber daya manusia untuk memenuhi kehidupan sehari-hari seperti sandang dan pangan di Desa Denai Lama Kecamatan Pantai Labu memiliki pekerjaan yang rata-rata sebagai petani sangat jarang ditemukan bekerja tetap di kantoran, tetapi dengan adanya objek wisata yang di kelola oleh Bumdes membuat ekonomi masyarakat meningkat dan pendapatan mereka bertambah.

Seorang laki-laki berumur 40 tahun yang bernama Bapak Saiful bekerja sebagai buruh tani dan semenjak adanya objek wisata ini ia ada pekerjaan sampingan yaitu menjaga parkiran motor dan mobil walaupun hasilnya tidak seberapa tapi itu sangat membantu pemasukan uang dikantong dan apabila dengan bekerja ikhlas maka pekerjaan itu terasa ringan dan mendapatkan pahala, tidak hanya Bapak Saiful sendiri yang menjaga sebagai parkiran tetapi ada anak remaja lainnya yang ikut bekerja dalam hal itu ${ }^{10}$

Ibu Sumiati berumur 35 tahun pekerjaan sama dengan Bapak Saiful sebagai buruh tani, semenjak adanya objek wisata yang dibuat ini sangat membantu ekonomi nya karna ia bisa memasarkan jualannya di sekitaran objek wisata seperti jualan buah jeruk dan buah salak ${ }^{11}$

Ibu-ibu UMKM yang lainnya juga melakukan pemasaran jualan seperti hasil dari rumah produksi seperti buah melinjo disulap menjadi produk unik seperti kue dan dodol, cemilan manis berbahan dasar melinjo mirip seperti "churros", kue kering asal Meksiko, juga menjadi oleh-oleh kebanggaan dari Denai Lama, hasil dari usaha mikro, kecil, dan menengah (UMKM) masyarakat setempat. Warga Denai Lama saat

\footnotetext{
${ }^{10}$ Bapak Saiful, Ekonomi Masyarakat, Wawancara Pribadi, Desa Denai Lama, 16 Mei 2019, Pukul 10:00 WIB.

${ }^{11}$ Ibu Sumiati, Ekonomi Masyarakat, Wawancara Pribadi, Desa Denai Lama, 16 Mei 2019 11:00 WIB.
} 
ini hanya bisa memasarkan produk khasnya saat ada yang memesan dan juga saat bazar baik di tingkat Kecamatan maupun Kabupaten. Markomel, emping pisang dan keripik pisang menjadi cemilan yang laris di incar pembeli saat bazar. Harganya terbilang murah yakni Rp.10.000,- masing-masing untuk markomel dan emping pisang, sedangkan keripik pisang hanya dibanderol Rp.5.000,- dalam kemasan sedang.

Kepala Desa yang bernama Parnu juga berhasil memasarkan jajanan tersebut masuk ke kantin-kantin sekolah setelah melobi Dinas Pendidikan setempat. Emping dan keripik pisang pun, laris manis digemari anak sekolah karena di jual dengan harga terjangkau, yakni Rp.1.000,- dalam kemasan kecil.

Ibu Suyiati atau biasa di panggil Ibu Utet berusia sekitar 37 tahun ia tinggal di Desa Binjai Bakung Dusun III ia berjualan makan-makanan ringan, minuman dan juga makanan instan lainnya, ia bisa mendapatkan sehari itu hampir 1 juta waktu selagi ramai-ramainya seperti hari minggu lalu hari kedua ia mendapatkan 900 ribu dan hari ketiga 800 ribu dibandingkan jualan dirumah Ibu Suyiati dapat sehari mau 500 ribu maka ia memutuskan jualan di depan objek wisata hasilnya lumayan dibandingkan jualan dirumah, jika ada pengunjung yang datang bisa menikmati makanan yang ia jual. Jarak untuk menempuh ketempat lokasi wisata Ibu Suyiati harus menempuh sekitar 20 menit untuk ke tempat Desa Denai Lama yang mana tempat ia berjualan walaupun yang ia jual hanya sederhana tetapi peminatnya sangat banyak membuat tingkat ekonomi nya bertambah dibandingkan ia berjualan $\operatorname{dirumah}^{12}$.

\section{Faktor Pendukung Pengelolaan Objek wisata}

Salah satu faktor pendukung dalam pengelolaan objek wisata yaitu di dukung oleh Bupati Deli Serdang dan Dinas Pariwisata. Bupati Deli serdang yang bernama H.Ashari Tambunan berharap objek wisata ini akan menambah pendapatan bagi warga sekitar dan menciptakan lapangan pekerjaan. Faktor pendukung lainnya seperti

\footnotetext{
${ }^{12}$ Ibu Suyiati, Ekonomi Masyarakat, Wawancara Pribadi, Desa Denai Lama, 16 Mei 2019 Pukul 12:30 WIB. 
infrastruktur juga merupakan sarana pendukung aktivitas kepariwisataan seperti pembangunan jalan membuat para wisatawan mudah mengakses perjalanan baik mengendarai motor maupun mobil. Rumah makan, dan jualan di pinggiran objek wisata juga sarana faktor pendukung banyaknya para peminat pengunjung datang karena bisa menikmati makan siang dan cemilan yang berada di sekitar objek wisata. Harga tiket untuk masuk juga sangat terjangkau tidak menguras kantong dengan membayar Rp.5000,- para pengunjung sudah menikmati sejuknya pemandangan di area persawahan dihiasi langit yang biru sambil mengabadikan moment bersama keluarga dan teman. Para pengunjung yang datang juga bisa memparkirkan kendaraan nya di tempat area parkiran sangat aman yang sudah di sediakan dengan sapta pesona aman, tertib, bersih, sejuk, indah, ramah tamah dan kenangan. Faktor pendukung lainnya dalam menarik wisatawan, Denai Lama saat ini tengah memperbanyak jumlah rumah warga yang bisa dijadikan penginapan "homestay". Saat ini baru ada lima rumah yang siap ditempati wisatawan. Pengunjung akan ditawarkan paket wisata untuk tiga hari atau seminggu, mulai dari belajar kerajinan tangan sampai belajar Tari Serampang Duabelas

\section{Faktor Penghambat Pengelolaan Objek wisata}

Salah satu faktor penghambat dalam pengelolaan objek wisata yaitu Pertama, permodalan karena permodalanlah yang salah satu objek pemasukan untuk membangun pembangunan selanjutnya baik sarana transportasi dan infrastruktur. Kedua, sampai saat ini pengurus Bumdes belum menyediakan tempat untuk Sholat (Musholla) yang membuat para pengunjung ingin melaksanakan sholat 5 waktu harus mengakses perjalanan lagi mencari musholla terdekat seharusnya pengurus Bumdes membuat tempat ibadah sekitar objek wisata yang akan memudahkan para pengunjung untuk melaksanakan ibadah dan istirahat dan mengingatkan mereka bahwa untuk Sholat tepat waktu. Ketiga, tidak tersedianya toilet untuk membuang air kecil/air besar, seharusnya pengurus Bumdes dan masyarakat lainnya adanya inisiatif untuk membangun tempat membuang air kecil/air besar sehingga para pengunjung 
yang datang lebih merasa nyaman dan senang di sediakan sarana yang lengkap. Keempat, faktor penghambat yang lainnya yaitu saat cuaca tidak mendukung seperti hujan, saat hujan datang maka itu menjadi para pengunjung tidak bisa bepergian jauh atau menikmati suasana pemandangan di objek wisata. Kelima yaitu saat musim panen tiba maka para petani akan turun ke sawah untuk memanen hasilnya. Padi yang tumbuh sekitar 6 bulan sekali, jika sudah panen maka sedikit wisatawan yang berkunjung, untuk menunggu objek wisata indah di pandang harus menunggu waktu yang lama sekitar 5 atau 6 bulan $^{13}$

\section{PENUTUP}

Berdasarkan penjabaran yang dijelaskan pada hasil penelitian dan pembahasan Peran Badan Usaha Milik Desa Dalam Pengelolaan Objek Wisata Di Desa Denai Lama Kecamatan Pantai Labu Kabupaten Deli Serdang, maka kesimpulan yang diperoleh adalah :

1. Program Badan Usaha Milik Desa dalam mengelola objek wisata di Desa Denai Lama Kecamatan Pantai Labu Kabupaten Deli Serdang sudah banyak di lakukan pihak Bumdes yaitu menyediakan fasilitas jembatan bambu, Spot foto, Pusat Kegiatan Belajar Masyarakat-rumah produksi (PKBM) dan Budaya Sanggar Tari. Pihak Bumdes meningkatkan ekonomi masyarakat melalui objek wisata yang membuat para pedagang membuka usaha jualan di sekitar area objek wisata. Selain program objek wisata, masih ada program rumah produksi yang di kelola oleh ibu UMKM mendapatkan peningkatan ekonomi seperti pembuatan kue, dodol dari bahan melinjo dan kerajinan tangan dari bahan batok kelapa serta kerajinan anyaman lidi.

2. Peningkatan ekonomi masyarakat setelah adanya objek wisata di Desa Denai Lama mendapatkan respon dan dampak positif terhadap peningkatan ekonomi masyarakat seperti menjaga parkiran, dan berjualan di sekitar area objek wisata.

\footnotetext{
${ }^{13}$ Halim Syahbana, Sekretaris Bumdes, Faktor Pendukung dan Penghambat, Wawancara Pribadi, Sanggar Lingkaran, 16 Mei 2019 Pukul 13.30 wib. 
Desa Denai Lama memiliki rumah produksi yang dikelola oleh ibu UMKM, ibuibu tersebut tidak hanya memasarkan hasil produk mereka tetapi mereka juga bisa melatih para pengunjung yang datang ke objek wisata dengan memesan paket belajar membuat kue, dodol dari melinjo dan kerajinan tangan dari bahan limbah yang di latih oleh ibu UMKM, maka hasil pemasaran produk ibu-ibu UMKM mengalami peningkatan ekonomi.

3. Salah satu faktor pendukung dalam pengelolaan objek wisata yaitu a) Bupati Deli Serdang dan Dinas Pariwisata telah meresmikan Desa wisata hal ini menunjukkan keseriusan Pemerintah dalam membangkitkan objek-objek wisata di daerah Deli Serdang b) Faktor pendukung selanjutnya seperti infrastruktur pembangunan jalan merupakan sarana pendukung aktivitas kepariwisataan membuat para wisatawan mudah mengakses perjalanan baik mengendarai motor maupun mobil. c) Faktor pendukung terakhir yaitu rumah warga juga bisa di jadikan penginapan "homestay" bagi para pengunjung yang sedang bepergian jauh dan harus menempuh waktu pulang yang sangat lama.

4. Faktor penghambat dalam pengelolaan objek wisata yaitu a) Permodalan dalam pembangunan objek wisata seperti pembangunan tempat ibadah dan toilet di daerah objek wisata tidak disediakan b) Tidak tersedianya transportasi umum seperti angkot arah menuju ke tempat wisata yang membuat kendala para wisatawan yang ingin berkunjung c) Cuaca tidak mendukung seperti hujan dan saat terjadi panen.

\section{DAFTAR PUSTAKA}

Adisasmita Rahardjo. 2014, Pengeloaan Pendapatan dan Anggaran Daerah (Yogyakarta : Graha ilmu )

Bungin Burhan. 2007, Penelitian Kualitatif, ( Jakarta : Prenada Media Group )

Damsar. 2011, Pengantar Sosiologi Ekonomi, (Jakarta : Kencana )

Deliarnov. 2015, Perkembangan Pemikiran Ekonomi, (Jakarta : Rajawali Pers )

Hari Karyono. A. 1997, Kepariwisataan, ( Jakarta : PT Grasindo ) 
Harrison Lisa. 2007, Metodologi Penelitian Politik, ( Jakarta : Kencana )

Kementrian Agama RI. 2013, Al-Quran Al-Karim dan Terjemahnya ( Surabaya : Halim Publishing \& Distributing )

Maria Rosa Ratna Sri Anggraeni. 2016, Peranan Badan Usaha Milik Desa Pada Kesejahteraan Masyarakat Pedesaan Studi Pada Bumdes Di Gunung Kidul, Yogyakarta ( Jurnal MODUS Vol.28 (2) : 155-157 )

Munawaroh Siti, Dkk, 1999, Peranan Kebudayaan Daerah dalam Perwujudan Masyarakat Industri Pariwisata, ( Yogyakarta : Departemen Pendidikan dan Kebudayaan ).

Tirtawinata Reza dan Fachruddin Lisdiana. 1996, Daya Tarik dan Pengelolaan Agrowisata ( Jakarta : Penebar Swadaya )

Rina Nurliani. 2018, dkk, Peran Kepala Bumdes dalam Pengeolaan Badan Usaha Milik Desa di Desa Padang Jaya Kecamatan Kuaro Kabupaten Paser (Universitas Mulawarman)

Rachmat, Sunarto, dkk. 2007, Pendidikan lingkungan dan Budaya, ( Jakarta : Ganeca Exact )

Ruslan Rosady. 2017, Metode Penelitian Public Realitions dan Komunikasi, (Jakarta: Rajawali Pers)

Setiadi, Elly M. 2006, Ilmu Sosial dan Budaya Dasar, ( Jakarta : Kencana Prenanda Media Group )

Situmorang SM. 2012, Objek wisata Kebun binatang Simalingkar B dalam kajian Sejarah Pariwisata tahun 2005-2011, (Medan : Universitas Negeri Medan, 2012)

Silalahi Ulber.2009, Metode Penelitian Sosial, ( Bandung : PT Refika Aditama )

Soekadijo R.G. 1996, Anatomi Parawisata, ( Jakarta : PT Gramedia Pustaka Utama )

Suwantoro Gamal. 2004, Dasar-dasar pariwisata, ( Yogyakarta : ANDI )

Widjaja A.W.1996, Pemerintahan Desa dan Administrasi Desa ( Jakarta : PT Raja Grafindo Persada 


\section{JURNAL PEMBERDAYAAN MASYARAKAT 168 \\ Volume 6 No. 2 Tahun 2018 ISSN: 2355-8679}

https://www.pariwisatasumut.net di akses tanggal 5 Februari 201910.30 wib.

https://travellingyuk.com.agrowisata.palohnaga diakses tanggal 05 Februari 2019

10.30 wib

www.dpr.go.id/uu/UU_2014_6 diakses tanggal 22 Maret Pukul 07.54 Wib 